ppi $201502 Z U 4645$

Esta publicación científica en formato digital es continuidad de la revista impresa ISSN-Versión Impresa 0798-1406 / ISSN-Versión on line 2542-3185Depósito legal pp $197402 Z$ U34
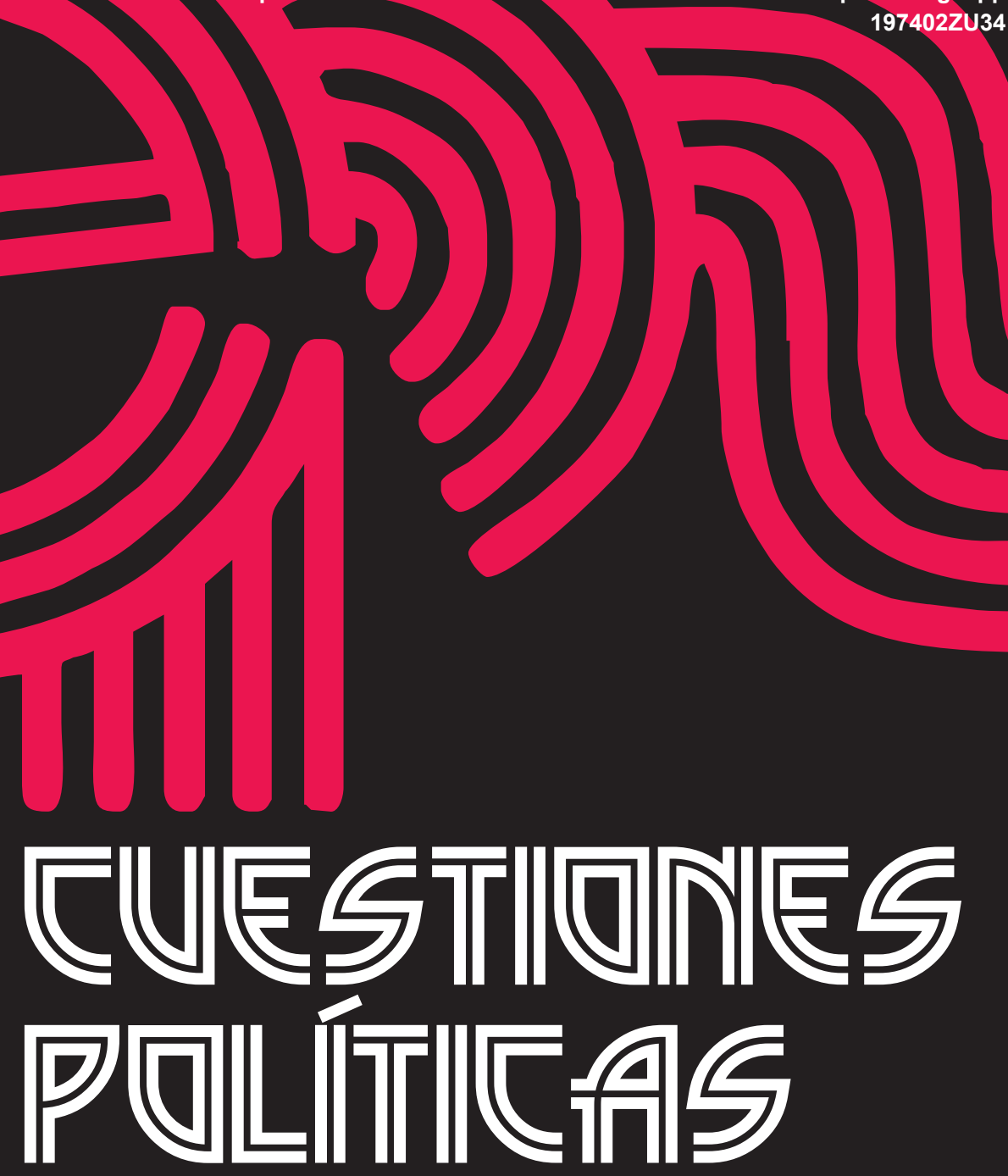

Instituto de Estudios Políticos y Derecho Público "Dr. Humberto J. La Roche" de la Facultad de Ciencias Jurídicas y Políticas de la Universidad del Zulia Maracaibo, Venezuela
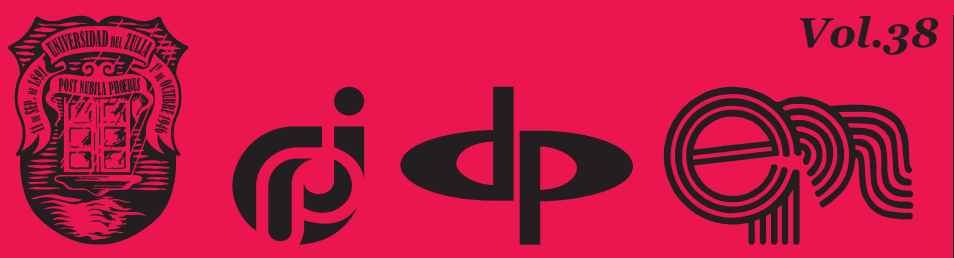

$N^{\circ}$ Especial 2da Parte 2020 


\title{
Environmental crime: dialectical and criminological vision
}

\author{
DOI: https://doi.org/10.46398/cuestpol.382e.24
}

\author{
Stanislav Igorevich Golubev * \\ Julia Viktorovna Gracheva ** \\ Sergey Vladimirovich Malikov *** \\ Alexander Ivanovich Chuchaev ****
}

\begin{abstract}
Traditionally, environmental crimes have been difficult to penalize both in Russia and abroad. Russian environmental legislation is not codified, it is a complex conglomerate of a wide variety of legal acts that are condemned to take into account the classification of environmental crimes and their delimitation of related crimes. Accordingly, the article examines the status, causes and some measures to prevent environmental crimes. The general methodological basis of the research was formed by the basic provisions of the dialectical method of the study of the phenomenon of legal in its text-context relationship. All the evidence can be concluded that the reasons for the production of environmental crimes include the ineffectiveness of the activities of law enforcement agencies, economic determinants and reasons in the field of legal awareness. In addition, the analysis of the statistical table of environmental crimes recorded a clear disproportion between the real situation in the field of ecology and the fight against such crimes. At the same time, the most significant factor that distorts the real image of environmental crimes is there and recursion
\end{abstract} latency in the concrete.

Keywords: Environmental crimes; legal dialectic; statistics on environmental crimes; causes of environmental crimes; prevention of environmental crimes in Russia.

* Law Faculty, Department of Criminal Law, Kazan Federal University. ORCID ID: https://orcid. org/oooo-0002-4725-1398. Email: s.golubev16@rambler.ru

** Faculty of Law, Department of Criminal Law, Moscow State Law University O.E. Kutafina. ORCID ID: https://orcid.org/oooo-0o02-3341-7422. Email: mega.sppa@mail.ru

*** Faculty of Law, Department of Criminal Law, Moscow State Law University O.E. Kutafina. ORCID ID: https://orcid.org/oooo-0003-0892-2328. Email: SMalikov@rambler.ru

****Faculty of Law, Department of Criminal Law, Moscow State Law University O.E. Kutafina, A Chuchaev. ORCID ID: https://orcid.org/oooo-0002-5144-052X. Email: Ivanovich@rambler.ru

Recibido el 04/05/2020 Aceptado el 08/24/2020 
Stanislav Igorevich Golubev, Julia Viktorovna Gracheva, Sergey Vladimirovich Malikov y Alexander Ivanovich Chuchaev

\section{Crimen ambiental: visión dialéctica y criminológica}

\section{Resumen}

Tradicionalmente, los delitos ambientales han sido difíciles de penalizar tanto en Rusia como en el extranjero. La legislación ambiental rusa no está codificada, es un conglomerado complejo de una gran variedad de actos legales regulatorios que deben tenerse en cuenta durante la calificación de delitos ambientales y su delimitación de los delitos relacionados. En consecuencia, el artículo examina el estado, las causas y algunas medidas para prevenir los delitos ambientales. La base metodológica general de la investigación se formó por las disposiciones básicas del método dialéctico del estudio del fenómeno jurídico en su relación texto y contexto. Toda la evidencia permite concluir que, las razones de la producción de delitos ambientales incluyen la ineficacia de las actividades de los organismos encargados de hacer cumplir la ley, los determinantes económicos y las razones en el campo de la conciencia jurídica. Además, el análisis del cuadro estadístico de los delitos ambientales registrados indica una clara desproporción entre la situación real en el campo de la ecología y la lucha contra esos delitos. Al mismo tiempo, el factor más significativo que distorsiona la imagen real de los delitos ambientales es su latencia y recursividad en la realidad concreta.

Palabras clave: Delitos ambientales; dialéctica jurídica; estadísticas sobre delitos ambientales; causas de los delitos ambientales; prevención de delitos ambientales en Rusia.

\section{Introduction}

Traditionally environmental crimes are difficult to enforce both in Russia and abroad (White, 2008; Borrillo, 2016; Görgényi, 2018; Paraschiv, 2018; Orellana, 2005). The situation in our country is complicated by the fact that legal regulation in the field of ecology is carried out on a multilevel basis: both federal legislation and the legislation of the constituent entities of the Russian Federation take place. Besides, environmental legislation is not codified, it is a complex conglomerate of a large array of normative legal acts that must be taken into account during environmental crime qualification, and their delimitation from related offenses.

Traditionally criminal law theorists consider this group of crimes as a single one, which is due to the object of criminal law protection - the natural environment and its components, and accordingly the existing structure of the RF Criminal Code (Bratashova, 2011; Kopylov, 2004; Kudryavtsev, 2012; 
Pleshakov, 1993; Stolyarov, 2001). At the same time, the most widespread in domestic criminal law is the understanding of environmental crimes as an integral part of encroachments on public safety, which pushes scientists to determine the object of such socially dangerous acts as environmental safety (Brinchuk, 2001; Zhavoronkova and Shpakovsky, 2012; Petrova, 2005; Krasnova, 2014).

The analysis of Russian legislation allows us to conclude that the term "environmental safety" is used haphazardly (Explanatory note to the draft decree by the President of the Russian Federation "On approval of environmental safety strategy for the Russian Federation during the period up to 2025", 2019) despite the special Federal Law No. 7-FL (2002) "On Environmental Protection", which introduced the concept of environmental safety as a state of protection of natural environment and vital interests of a person from the possible negative impact of economic and other activities, emergency situations of natural and man-made nature, and their consequences (Federal Law No. 7-FL "On Environmental Protection", 2002). All crimes combined in chap. 26 of the RF Criminal Code, taking into account their features, violate some side (aspect, element) of environmental safety, harm the safety of the environment as a whole or its individual components (surface or underground waters, sources of drinking water supply; atmospheric air; marine environment; land; subsoil; aquatic biological resources; wild animals and birds; forest plantations).

Currently, the national security in the Russian Federation is carried out through strategic planning (Federal Law No. 172-FL "On Strategic Planning in the Russian Federation", 2014). The ecological safety of the Russian Federation is considered as an integral part of national security, and the state of the environment on the territory of the state, where the majority of the country population, production facilities and the most productive agricultural lands (accounting for about $15 \%$ of the country territory) are concentrated, is assessed as unfavorable (The decree of the RF President No. 176 "On the Strategy of Environmental Safety of the Russian Federation during the Period up to 2025”, 2017).

\section{Materials and methods}

The general methodological basis of the study was formed by the basic provisions of the dialectical method of phenomenon study. Besides, a set of methods for social and legal reality cognition was used, which make it possible to study comprehensively the main directions and features of theory and practice, qualitative changes occurring in the development of the studied phenomena: general scientific (comparison, analysis, synthesis, induction, deduction), as well as particular scientific methods (formallogical, system-structural). 
Stanislav Igorevich Golubev, Julia Viktorovna Gracheva, Sergey Vladimirovich Malikov y Alexander Ivanovich Chuchaev

The empirical basis of the study was the following: published judicial practice in the form of clarifications of the RF Supreme Court Plenum; the statistical data of Rosstat (2016-2018), and the Supreme Court of the Russian Federation (2007-2018); analytical and informational materials of the RF Ministry of Internal Affairs; published data of sociological and criminological studies concerning the problems of environmental crimes.

\section{Results and discussion}

The state of the environment and its components as a source of threats to environmental safety (State report "On the state and protection of the RF environment in 2018", 2019). Despite the measures taken to reduce the levels of environmental impact by chemical, physical, biological and other factors, to prevent natural and man-made emergencies, including the emergencies at hazardous production facilities, to adapt economic sectors to unfavorable climate changes, the threats to environmental safety remain.

The state of atmospheric air in cities is still one of the main threats. In 2018, the content of pollutants remained at a high level. The level of air pollution was characterized as high and very high in 46 cities with the total population of 13.4 million people. The total volume of pollutant emissions into the atmospheric air in 2018 almost does not change as compared to 2010; Since 2014, there has been a continuous increase of pollutant emissions into the atmosphere (+ 3.5\%), and since 2012 there has been the redistribution of emissions: the volume of emissions from stationary sources has decreased by $13.1 \%$, and the volume of emissions from mobile sources has increased by $18,9 \%$.

The volume of water resources in the Russian Federation as a whole amounted to 4,622.6 $\mathrm{km}^{3}$ (2018); most of it (95\%) is formed within the country. The water content of the rivers exceeded the norm by $8.8 \%$; as compared to 2017 , it decreased by $1.3 \%$. The changes in the water reserves of the largest lakes in the Russian Federation were characterized by multidirectional trends: the increase of the lake Baikal and Khanka reserves and a relatively insignificant decrease of Ladoga and Onega lake reserves. Extremely high pollution and high pollution of surface fresh waters were registered in 2743 cases for 35 main pollutants. The largest number of cases (about 78\%) was noted in the basins of the Volga, Ob and Amur rivers. Since 2009, the indicator dynamics concerning the number of such cases has shown the tendency to some decrease. In 2018, 17 accidents were registered at surface freshwater facilities in the Russian Federation. The pollution of transboundary watercourses was estimated at the level of the previous periods. 
During the period of 2009-2018 almost all water basins of the Russian Federation demonstrated some decrease or stabilization of water intake volume from natural sources. The volume of wastewater discharges into surface natural water bodies of the Russian Federation in 2018 amounted to $40,059.02$ million $\mathrm{m}_{3}$, which is $18.6 \%$ lower than the level of 2010 . The cities of the Russian Federation also demonstrated a general trend towards the volume of polluted wastewater discharge decrease into surface water bodies (2011-2018).

The problem of land degradation, soil and vegetation cover as the result of water and wind erosion, waterlogging, salinization and alkalinization, and desertification remains difficult. More than a third of the agricultural land area is affected by this, and the total area of eroded, deflated and deflation-hazardous agricultural land in the Russian Federation makes over $50 \%$, and the share of eroded and deflated soils continues to increase. The areas of soils that are saline, polluted and littered with industrial and household waste are growing. For the period of 2014-2018 the number of constituent entities of the Russian Federation with contaminated territories, and the types of pesticides, the content of which exceeds the standard were decreased.

The area of dead forest plantations on the lands of the forest fund amounted to 186.3 thousand hectares in 2018. The main reasons for the destruction of forest stands in 2018 were forest fires ( 73 thousand hectares, or $39.16 \%$ ), insect damage (72.2 thousand hectares, or $38.76 \%$ ), weather conditions and soil and climatic factors (16.1 thousand hectares, or $8.7 \%$ ), forest diseases (23.9 thousand hectares, or 12.81\%).

Detailed statistical indicators of the environment state are shown in Table 1.

\section{TABLE 1. Key indicators characterizing the impact of economic activities on the environment and natural resources in the Russian Federation (2016-2018)}

\begin{tabular}{|l|c|c|c|}
\hline & $\mathbf{2 0 1 6}$ & $\mathbf{2 0 1 7}$ & $\mathbf{2 0 1 8}$ \\
\hline Emissions of air pollutants - total, million tons & 31,6 & 32,1 & 32,3 \\
\hline $\begin{array}{l}\text { including: } \\
\text { from stationary sources }\end{array}$ & 17,3 & 17,5 & 17,1 \\
\hline from mobile sources & 14,3 & 14,6 & 15,2 \\
\hline $\begin{array}{l}\text { Capture and neutralization of pollutants from } \\
\text { stationary sources, million tons }\end{array}$ & 49,2 & 50,7 & 46,7 \\
\hline
\end{tabular}


Stanislav Igorevich Golubev, Julia Viktorovna Gracheva, Sergey Vladimirovich Malikov y Alexander Ivanovich Chuchaev

\begin{tabular}{|l|c|c|c|}
\hline & $\mathbf{2 0 1 6}$ & $\mathbf{2 0 1 7}$ & $\mathbf{2 0 1 8}$ \\
\hline $\begin{array}{l}\text { Water intake from natural water sources for } \\
\text { use, billion } \mathrm{m}^{3}\end{array}$ & 61,3 & 59,7 & 59,7 \\
\hline Water losses during transportation, billion $\mathrm{m}^{3}$ & 6,8 & 7,0 & 7,0 \\
\hline $\begin{array}{l}\text { Recycling and consistent use of water, billion } \\
\mathrm{m}^{3}\end{array}$ & 137,9 & 138,7 & 144,2 \\
\hline $\begin{array}{l}\text { Share of the population provided with } \\
\text { poor-quality drinking water from the total } \\
\text { population, \% }\end{array}$ & 5,8 & 5,2 & 4,8 \\
\hline $\begin{array}{l}\text { Discharge of contaminated wastewater, billion } \\
\text { m }^{3}\end{array}$ & 14,7 & 13,6 & 13,1 \\
\hline $\begin{array}{l}\text { Production and consumption waste } \\
\text { generation, million tons }\end{array}$ & 5441 & 6221 & 7266 \\
\hline including dangerous ${ }^{6}$ & 98 & 108 & 98 \\
\hline $\begin{array}{l}\text { Utilization and neutralization of production } \\
\text { and consumption waste, million tons }\end{array}$ & 3244 & 3265 & 3818 \\
\hline Reforestation, thousand ha & 840 & 962 & 940 \\
\hline
\end{tabular}

Source: (http: //old.gks.ru)

\subsection{Causes of environmental crime}

The crime factors in the field of ecology are in the focus of research by domestic criminologists, but most scientists only point to such determinants as weak state control over natural resource protection, defective environmental legislation, public apathy towards lawbreakers and a high level of latency (Vypkhanova, 2006; Zhevlakov, 2002; Savichenko, 2004).

All this is manifested in the untimely sending by the regulatory authorities of the materials on the identified environmental crimes to law enforcement agencies; low level of these materials; irregular inspections of business entities based on the results of previously issued instruction execution, etc (Ditsevich, 2008). Other objective factors also include the presence of obstacles that impede the implementation of public monitoring of sentences, decisions and judicial acts in cases of environmental legal relations; the quality of the methods used for statistical observations of environmental crimes that does not meet real needs, the lack of alternative, scientifically grounded and tested methods among them (Tatyanina et al., 2019). 
The presence of these factors is indisputable, but not enough. It is not enough to see among the causes of environmental crimes only the ineffectiveness of law enforcement agency work. Economic determinants and the process of the country urbanization can be singled out as the fundamental causes of environmental crime. The first is that ensuring environmental safety is associated with huge costs for the implementation of all rules and regulations in the field of environmental protection. Compliance with all the requirements of regulatory enactments multiplies costs, making economic activities unprofitable. Therefore, many business entities neglect environmental safety and violate the law, guided by considerations of profitability of production and increased profits.

From the point of view of an economic entity, the threat of an environmental catastrophe cannot be put higher than the fact that an enterprise, while functioning effectively, provides people with jobs, makes a profit, and pays taxes to the budget. For example, the deputies of the State Duma of the Russian Federation from the Primorsky and Khabarovsk Territories have developed a bill proposing to prohibit the transshipment of coal in the open way within settlements, which caused a violent reaction from other parliamentarians and economists, indicating that the industry generates considerable income (Dust storm, 2017). The state itself is also interested in the enterprise, in spite of numerous violations of the law, in its work continuation, and the managers are ready to pay regularly the fines imposed by various regulatory authorities.

Other economic circumstances that determine the state of environmental crime include low living standards, unemployment, non-payment of wages, which leads to the spread of poaching, the cases of unauthorized seizure of land for personal needs, illegal felling of trees and bushes. These facts make up the largest share of environmental crimes, thereby distorting the very essence of this group of crimes, reflecting only its "grassroots" level.

Another inalienable factor that determines environmental crimes is the underdevelopment of environmental legal awareness, and sometimes its absence. Environmental awareness is a kind of legal awareness, and its emergence is conditioned by the growing threat of the global environmental crisis and the need to preserve human civilization.

\subsection{The statistical picture of environmental crime (Statistical data of the Ministry of Internal Affairs of Russia)}

This brief overview of environmental crime determinants needs to be compared with the available statistics. The analysis of such information allows us to conclude that until 2013, 99\% of environmental criminal cases 
Stanislav Igorevich Golubev, Julia Viktorovna Gracheva, Sergey Vladimirovich Malikov y Alexander Ivanovich Chuchaev

are initiated under 4 articles: the Art. 256 "Illegal extraction (catch) of aquatic biological resources", the Art. 258 "Illegal hunting", the art. 260 "Illegal felling of forest plantations", the art. 261 "Destruction or damage of forest plantations". The rest of the crimes account for less than $1 \%$ of the initiated criminal cases (see Table 2; Fig. 1.2).

\section{TABLE 2. The number of registered environmental crimes in the Russian Federation (2007-2018)}

\begin{tabular}{|c|c|c|c|c|c|c|c|c|c|c|c|c|}
\hline & 2007 & 2008 & 2009 & 2010 & 2011 & 2012 & 2013 & 2014 & 2015 & 2016 & 2017 & 2018 \\
\hline art. 246 & 29 & 11 & 6 & 5 & 4 & 7 & 5 & 24 & 14 & 19 & 32 & 23 \\
\hline art. 247 & 84 & 42 & 40 & 21 & 25 & 51 & 23 & 31 & 36 & 44 & 124 & 70 \\
\hline art. 248 & o & o & o & o & o & 0 & o & o & o & 0 & 0 & 0 \\
\hline art. 249 & 3 & 6 & 11 & 2 & 2 & 20 & 1 & 4 & o & 5 & 9 & 9 \\
\hline art. 250 & 32 & 28 & 19 & 19 & 17 & 15 & 13 & 17 & 29 & 28 & 40 & 39 \\
\hline art. 251 & 20 & 7 & 9 & 4 & 2 & 4 & 5 & 2 & 6 & 7 & 13 & 13 \\
\hline art. 252 & 13 & 11 & 10 & 12 & 5 & 5 & 2 & 7 & 3 & 3 & 5 & 4 \\
\hline art. 253 & 26 & 17 & 24 & 19 & 17 & 12 & 9 & 10 & 2 & 13 & 8 & 8 \\
\hline art. 254 & 27 & 27 & 24 & 24 & 33 & 63 & 74 & 73 & 85 & 64 & 202 & 182 \\
\hline art. 255 & 8 & 2 & 2 & o & o & 3 & o & 6 & 4 & 8 & 2 & 4 \\
\hline art. 256 & 18025 & 15841 & 17407 & 13644 & 8963 & 8172 & 7343 & 6566 & 6276 & 5469 & 5713 & 5976 \\
\hline art. 257 & 6 & 9 & 6 & 3 & 4 & 3 & 6 & 6 & 9 & 3 & 5 & 9 \\
\hline art. 258 & 1292 & 1186 & 1560 & 1540 & 1517 & 1613 & 1640 & 1615 & 1928 & 1906 & 1936 & 1931 \\
\hline art. $258^{1}$ & 0 & 0 & 0 & o & o & 0 & 74 & 924 & 1152 & 1210 & 1104 & 1120 \\
\hline art. 259 & o & o & o & 1 & o & 2 & o & 1 & o & o & o & o \\
\hline art. 260 & 19128 & 23802 & 24932 & 20826 & 16077 & 15795 & 14640 & 14834 & 14192 & 14233 & 14422 & 13763 \\
\hline art. 261 & 2487 & 3824 & 2461 & 2925 & 2393 & 1753 & 861 & 1381 & 1063 & 598 & 690 & 642 \\
\hline art. 262 & 62 & 70 & 96 & 110 & 92 & 65 & 47 & 65 & 58 & 78 & 74 & 106 \\
\hline Total & 41242 & 44883 & 46607 & 39155 & 29151 & 27583 & 24743 & 25566 & 24857 & 23688 & 24379 & 23899 \\
\hline
\end{tabular}

Source: https://en.mvd.ru/. Statistical data of the Ministry of Internal Statistical data of the Ministry of Internal. 


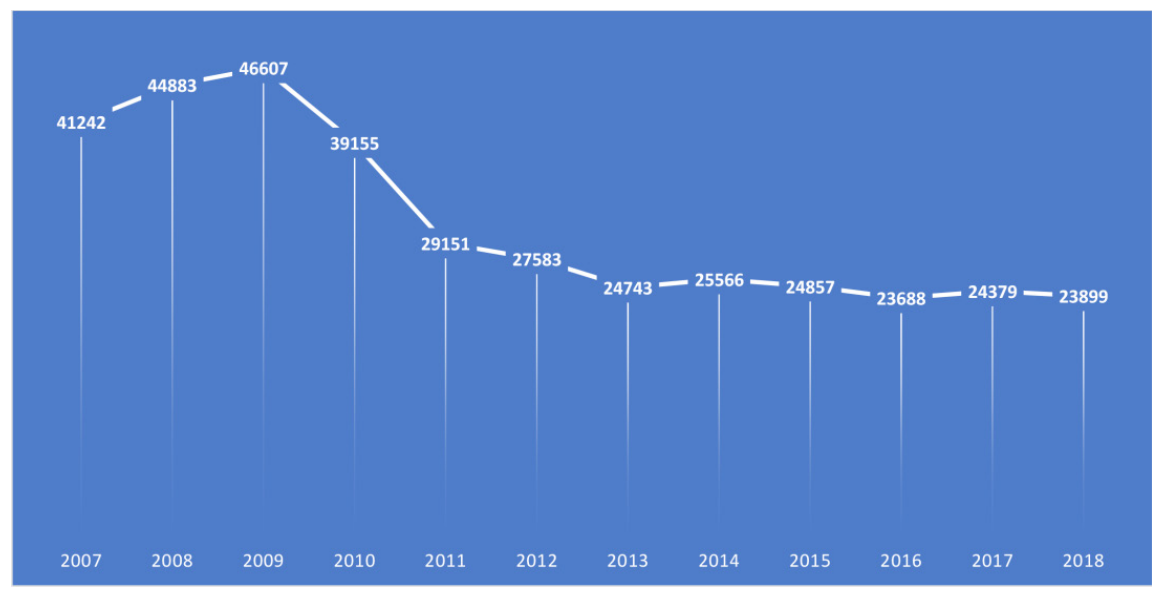

FIGURE 1. Dynamics of registered environmental crimes in the Russian Federation (2007-2018)

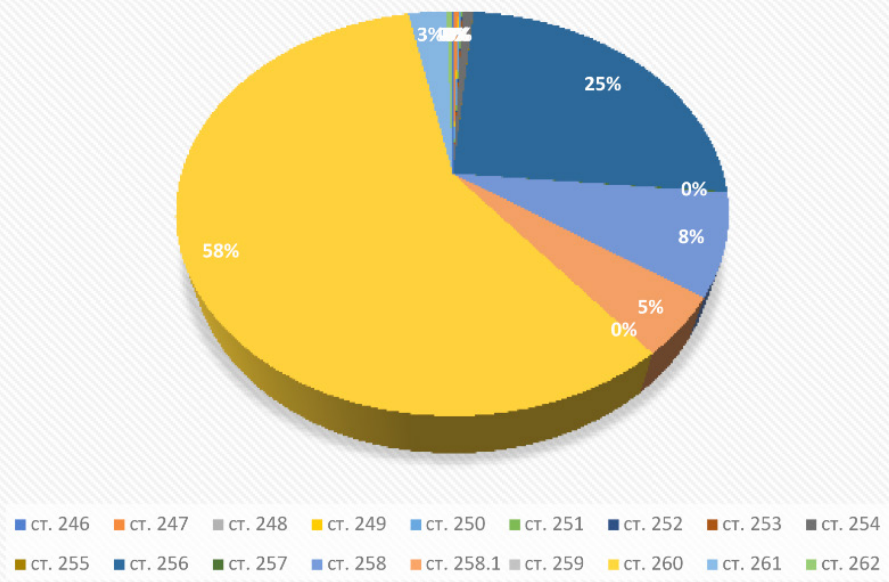

FIGURE 2. The proportion of certain environmental crimes in the Russian Federation (2018)

The presented picture of registered environmental crimes testifies to a clear disproportion between the real state of affairs in the field of ecology and counteraction to such crimes. As was noted earlier, the main threats are air and water pollution; high degree of pollution and low water quality of a significant part of water bodies, degradation of ecosystems of small 
Stanislav Igorevich Golubev, Julia Viktorovna Gracheva, Sergey Vladimirovich Malikov y Alexander Ivanovich Chuchaev

rivers, technogenic pollution of groundwater in the areas where large industrial enterprises are located; production and consumption waste generation increase with a low level of their utilization; increased land and soil degradation, reduction of plant species; reduction of the animal world species diversity and the number of rare species of animals, etc. The number of cases initiated on such facts is minimal in the country.

One of the reasons for this disproportion, along with the previously indicated determinants of crime, may be the difficulty in qualifying and proving the crimes in question. In particular, environmental crimes are expressed in non-compliance with the requirements established by environmental legislation. When they initiate a criminal case, a problem often arises concerning establishing a causal relationship between an act and the resulting consequences. The difficulty is in the fact that a significant amount of time may pass between the act and the consequences that have occurred, or the actions taken to hide the crime traces. You also need to remember that a causal relationship in a criminal case will be absent if the resulting consequences to nature or humans occur as the result of natural or other factor impact. Thus, it is necessary to find out whether these consequences were caused by natural factors.

The factor that distorts the real picture of environmental crime is its latency, which affects the idea of such crime actual state, its structure and dynamics, the magnitude and nature of the damage caused. Almost all Russian scientists noted this fact (Dvoretsky, 2013; Dzikonskaya, 2011; Akutaev, 1997). The following can be distinguished as its reasons:

- Ignorance of citizens about the violation of their environmental constitutional rights, causing environmental harm.

- Conviction of citizens in the imperfection of the current criminal and environmental legislation, as well as disbelief in law enforcement agencies (in the possibility, mechanisms of disclosure, investigation of environmental crimes, protection of their rights as the victims of environmental crimes).

- Unwillingness to contact law enforcement agencies and burden oneself with the need to participate in a complex procedure related to an environmental crime investigation.

- Imperfection of the procedure for a criminal case initiation.

- Problems of application of norms regulating the liability for environmental crimes.

- Lack of a support system (technical, informational, personnel) for the disclosure and investigation of environmental crimes.

- The influence of corruption-generating factors, etc. 


\section{Conclusions}

The socio-legal and criminological conditionality of responsibility for environmental crimes is expressed in the presence of a number of problems, both interstate and domestic, that do not allow to guarantee effective counteraction to these negative manifestations. The solution of these problems is possible only through the implementation of a set of economic, legislative, organizational-political, social, educational and international measures:

- Elimination of contradictions between natural resource and environmental protection norms of the RF legislation (ALSO by developing a concept of environmental legislation development).

- Consolidation of the need to present an environmental justification for the activities of economic entities as one of the prerequisites for holding tenders, and auctions for the right to implement and (or) select projects.

- Harmonization of domestic legislation in the field of environmental protection and international law in this area within the framework of the RF obligations under international treaties.

- Development and activation of judicial mechanisms for resolving contradictions between the interests of the population, business entities and the state in the field of environmental protection.

- Improvement of calculation methods and compensation practice for damage as the result of environmental offenses and (or) implementation of environmentally hazardous activities.

- Provision of mechanism application for the termination of illegal economic and other activities.

An objective assessment of a crime situation is a necessary condition for countering environmental crime. The specificity of countering environmental crime lies in the need for a clear and constant provision of active and coordinated actions of all environmental, control and law enforcement agencies. As they indicated, the registered facts of environmental crime distort the very essence of this group of crimes, reflecting its "grassroots" level. The reasons for the production of an environmental crime include the ineffectiveness of law enforcement agency activities, economic determinants and the reasons in the field of legal consciousness. The analysis of the statistical picture of registered environmental crimes indicates a clear disproportion between the real state of affairs in the field of ecology and counteraction to such crimes, while the most significant factor distorting the real picture of environmental crime is its latency. 
Stanislav Igorevich Golubev, Julia Viktorovna Gracheva, Sergey Vladimirovich Malikov y Alexander Ivanovich Chuchaev

\section{Bibliographic References}

AKUTAEV, Rasul. 1997. "Latent criminality: actual problems and concept" In: State and law. Vol. 12, pp. 79-87.

BORRILLO, Daniel. 2016. "Ecological crimes and environmental criminal law: Reflections on the environmental criminal law in the European Union" In: Revista De Estudos Constitucionais, Hermenêutica e Teoria do Direito. Vol. 3, No. 1, pp. 1-14.

BRATASHOVA, Nevadia. 2011. “The concept of environmental crime” In: Legal culture. No. 1, pp. 222-225.

BRINCHUK, Mikhail Mikhailovich. 2001. The role of the state in environmental safety provision. Environmental safety, problems, search, solutions. Izdatelstvo "I Urlitinform. Moscow, Russia.

DITSEVICH, Yaroslava Borisovna. 2008. "On some factors that determine environmental crime" In: Criminological journal of OGUEP. Vol. 3, pp. 30-39.

DUST STORM .2017. Russian newspaper. Federal issue Available online. In: https://www.w3newspapers.com/russia/. Consultation date: 15/12/2019.

DVORETSKY, MikhailYu. 2013 "Problematic aspects of environmental crime prevention: questions of theory and law enforcement practice" In: Russian Justice. Vol. 5, pp. 68-70.

DZIKONSKAYA, Serge. 2011. The state and structure of environmental crime in Russia and the problems of its prevention. Ecology and criminal law: search for harmony. Krasnodar, Russia.

EXPLANATORY NOTE TO THE DRAFT DECREE BY THE PRESIDENT OF THERUSSIANFEDERATION “ONAPPROVALOFENVIRONMENTAL SAFETY STRATEGY FOR THE RUSSIAN FEDERATION DURING THE PERIOD UP TO 2025”. 2019. Available online. In: http://www. mnr.gov.ru/docs/strategii_i_doktriny / 142854 /. Consultation date: 15/12/2019.

FEDERAL LAW. 2002. No. 7-FL "On Environmental Protection". RLS "ConsultantPlus". Available online. In: http://www.consultant.ru/sys/ english/. Consultation date: 15/12/2019. 
FEDERAL LAW. 2014. No. 172-FL "On Strategic Planning in the Russian Federation". RLS "ConsultantPlus". Available online. In: http://www. consultant.ru/sys/english/. Consultation date: 15/12/2019.

GÖRGÉNYI, Ilona. 2018. "Protection of the environment through criminal law considering the european standards" In: Agrar - Es Kornyezetjog. Vol. 13, No. 25, pp. 46-80.

KOPYLOV, Mikhail Nikolaevich. 2004. Legal liability for environmental crimes. M Alucard. Moscow, Russia.

KRASNOVA, Irina. 2014. "Environmental safety as a legal category" In: Lex russica. Vol. 5, pp. 543-555.

KUDRYAVTSEV, Vasila. 2012. "Environmental crimes: general characteristics" In: Bulletin of the South Ural Professional Institute. Vol. 1, pp. 105-116.

SERVICIO DE ESTADÍSTICAS DEL ESTADO FEDERAL. 2018. “. Available online. In: http: //old.gks.ru. Consultation date: 23/12/2019.

ORELLANA, Marcos. 2005. "Criminal punishment for environmental damage: Individual and state responsibility at a crossroad" In: Georgetown International Environmental Law Review. Vol. 17, No. 4, pp. 673-696.

PARASCHIV, Daniel-Stefan. 2018. Particularities on the subjects of liability for the acts that harm the environment 1 . Research and science today. Rasovica, Romania.

PETROVA, Tatiana. 2005. "Technical regulation as the part of the system of legal regulation of relations in the field of environmental protection" In:Ecological Law. Vol. 1, Special issue, pp. 77-81.

PLESHAKOV, Andrey M. 1993. "Environmental crimes: concepts and system of concepts" In: State and law. Vol. 8, pp. 81-88.

SAVICHENKO, Iandre. 2004. "The problems of environmental crime investigation" In: Sib. law messenger. Vol. 1, pp. 48-52.

STATE REPORT "ON THE STATE AND PROTECTION OF THE RF ENVIRONMENT IN 2018”. 2019. Ministry of Natural Resources of Russia; SPE “Cadastre”. Available online. In: http://government.ru/en/ department/48/events/. Consultation date: 23/12/2019.

STATISTICAL DATA OF THE MINISTRY OF INTERNAL AFFAIRS OF RUSSIA. 2018. Reporting form 491. Available online. In: https://en.mvd. $\mathrm{ru} /$. Consultation date: 23/12/2019. 
Stanislav Igorevich Golubev, Julia Viktorovna Gracheva, Sergey Vladimirovich Malikov y Alexander Ivanovich Chuchaev

STOLYAROV, Vandi. 2001. "Criminal Law Analysis of Environmental Crimes" In: Environmental Law. Vol. 1, pp. 9-15.

TATYANINA, Levons; LUKOMSKAYA, Andre; YULDOSHEV, Rifat. 2019. "Concept, essence and modern prospects for the prevention of environmental crime in the Russian Federation" In: All-Russian criminological journal. Vol. 13, No. 1, pp. 103-113.

THE DECREE OF THE RF PRESIDENT. 2017. No. 176 "On the Strategy of Environmental Safety of the Russian Federation during the Period up to 2025". RLS “ConsultantPlus". Available online. In: http://www. mnr.gov.ru/docs/strategii_i_doktriny / 142854 /. Consultation date: 15/12/2019.

VYPKHANOVA, Ganva. 2006. "On the issue of information support for nature management and environmental protection: conceptual and legal aspects" In: Environmental law. Vol. 5, pp. 36-40.

WHITE, Rob. 2008. Crimes against nature: environmental criminology and ecological justice. Willan Publishing. London, England.

ZHAVORONKOVA, Natalia Grigorevana; SHPAKOVSKY, Yuri Grigoryevich. 2012. "State administration in the field of environmental safety: organizational and legal aspect" In: Bulletin of the Russian State Trade and Economic University. Vol. 7-8, pp. 204-209.

ZHEVLAKOV, Eliana. 2002. Criminal law protection of the RF natural environment. Izdatelstvo "I Urlitinform. Moscow, Russia. 

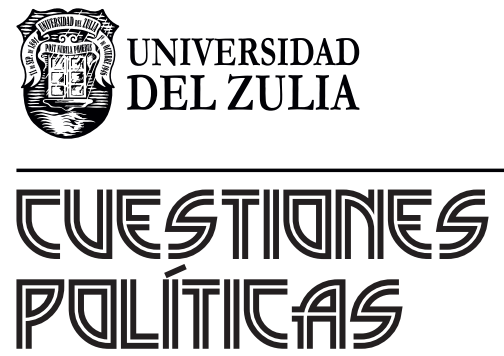

Vol.38 NEspecial

Esta revista fue editada en formato digital y publicada en diciembre de 2020, por el Fondo Editorial Serbiluz, Universidad del Zulia. Maracaibo-Venezuela 